\title{
Creativity Training Model for Game Design
}

\author{
Raudyah Md Tap ${ }^{1}$, Nor Azan Mat Zin², Hafiz Mohd Sarim³ , Norizan Mat Diah ${ }^{4}$ \\ Faculty of Information Science and Technology, The National University of Malaysia, 43600 Bangi, Malaysia, 2, 3 \\ Faculty of Computer and Mathematical Sciences, Universiti Teknologi MARA, 40450 Shah Alam, Selangor, Malaysia ${ }^{4}$
}

\begin{abstract}
The popularity of digital games is increasing with a global market value of RM197.6 billion. However, the game produced locally still has no impact. One reason is that there is no emphasis on the game design process in the game development education program. Games designed have a problem in terms of creativity, and there is still no specific method of training creative thinking. This study aims to identify and validate game design's creativity components and develop a Creativity Training Model for Game Design (LK2RBPD Model) verified through the Game Design Document Tool (GDD Tool) prototype. This research has four main phases: the requirements planning, design, development, implementation, and testing phases. In the requirements analysis phase, the component of LK2RBPD Model was identified. The LK2RBPD Model contains elements from industry practices of game designing, creative and innovative thinking skills, creativity dimensions, Sternberg Creativity, and Cultural Activity theories. The GDD Tool prototype implementing the model was developed and tested. The LK2RBPD Model was evaluated using questionnaire survey, SWOT (Strengths, Weaknesses, Opportunities, and Threats) analysis, and verification of ideas in the GDD Tool prototype. Evaluation using a five-point Likert scale shows that GDD Tool prototype is effective in implementing 19 components. Expert verification on the results of game design ideas and creativity building using Cohen Kappa calculations is 0.94, indicating an excellent agreement. The results show that the LK2RBPD Model can be effectively used to train creativity in game design. This research's contributions are LK2RBPD Model, creative game design ideation process guideline, and GDD Tool prototype design.
\end{abstract}

Keywords-Creativity training; game design; creative ideas; creative thinking

\section{INTRODUCTION}

Technological change is very significant, especially in information and communication technology (ICT), which has led to rapid development in various fields and aspects of life [1]. Changes in ICT have been particularly noticeable when the explosion of electronic and digital devices has dominated today's technology market. Digital games have also become a large industry, generating billion dollars worldwide. Despite the expansion, this industry is facing a number of problems [2]. The popularity of digital games is increasing, with a global market value of RM197.6 billion. However, the game produced locally still has no considerable impact. One reason is that there is no emphasis on the game design process in the game development education program.

Many digital games on various platforms have been created, either for entertainment or for other purposes. Various studies have shown the potential and effectiveness of computer games for education, they are found to be more efficient, beneficial, and of quality [3] [4] [5]. Regardless of the purpose of the computer games, the fundamental emphasis should be on the game design and the design process's creative aspect.

The game design process plays a crucial role in producing a good and creative game. According to [6], the process of game design is divided into two main phases that need to be emphasized, namely ideation and conceptualization. Ideation refers to the process of generating creative and innovative game design ideas, while conceptualization is to outline the concept in the form of game prototypes that involve programming, architecture, sound, and interface. According to [6], creating an interactive and effective computer game is a huge issue and challenge because various assumptions in the creating of a computer game can have a significant impact on users. This is further reinforced by [7] [8] in their studies, that three important elements are emphasized in the construction of computer games, namely, a creative resource involving graphics and sound, files involving creative graphic rules, and a game engine involving the control of every graphic and sound. According to [9], the game design process needs to have certain creativity based on the practice of human game designers and an advanced analogy with creativity in science, acceptable to computational achievements in the form of discovery systems. In addition, [10] [11] [12] also agreed on the need to generate game ideas that require creative strategies in game designing. According to a recent study by [13], an effort to create or adopt tools that increases team communication is necessary to maintain designers and programmers' working in a strong collaborative atmosphere to produce creative game designs. Thus, it can be concluded that the computer games design needs to be emphasized in the game development education.

Creativity is defined as a process that occurs to a human being and a quality that is natural and learned. According to [14] [15], creativity is the ability of those who excel in creative endeavors, reflecting the idea of the human imagination as an intuitive notion of skill. The author in [5] considered creation as the process of finding sufficient facts, problems, ideas, and solutions, with cognition, imagination, and judgment, i.e. creative problem-solving. The author in [14] deemed creativity as the creation for particular needs or purposes by incorporating elements connected to form new relationships. Issues in a game product involve issues of creative thinking in game design and development. Creativity and skills are among the most important aspects for a digital game developer and designer. Eighty percent of games are expected to fail in meeting their business objectives due to poor designs and lack of creativity [16]. Creativity is an essential constituent in the game design process, which 
requires creative ideas, storytelling, character design, interface design, environmental design, and animation [17]. Also, game design demands a continuous process which incorporates many important aspects, including discipline and creativity [18] [19].

Game designers still face difficulty determining players' needs; therefore, the game design process desperately needs a model to help solve innovation and creativity problems [20] [18] [21]. This indicates that the gaming industry can use a model that will help improve the game's quality. According to [22], a software product's design requires a good planning process and a systematic methodological guide to software development. According to [23], innovative and creative processes are among the essential elements of the game business model. Furthermore, the most effective activities toward achieving business success are innovative and creative processes [24].

Meanwhile, the game design process requires more quality resources for the gaming industry's creative development. According to the Official Portal of the Multimedia Development Corporation (MDEC 2019), despite sufficient resources to meet demands, existing talent sources indicate serious problems with quality and skills. Thus, a creative thinking learning model is needed to address the talent gap inherent in the country's creative industry and show that everyone needs to practice creative skills.

\section{RESEARCH METHODOLOGY}

This study uses a mixed-method design approach that combines qualitative and quantitative study design to collect systematic data [25] [26]. Data collection includes course document analysis, interviews, questionnaire surveys, SWOT analysis, and analysis of game design documents. This research used Rapid Application Development (RAD) methodology, which includes requirements planning, design, development, implementation, and testing phases. The data collected were from the activities of each phase.

\section{A. Requirements Planning Phase}

The requirements planning phase involved the collection of the required information at the beginning of the study. In this phase, issues and problems together with elements of the model were identified. The phase activities include unstructured interviews for game design practices from six game designers and three game design lecturers, analysis of game development course documents and program structure, students' final project evaluation reports, students' observations on the game design process, and the literature review. Fig. 1 shows a summary of the activities performed in this phase.

\section{B. Design Phase}

In the design phase, the elements identified are grouped and mapped into different components of the LK2RBPD Model. The four phases of design activities are (i) excluding/removing elements not suitable for use in creative skills training for game design, (ii) grouping of similar elements by categorizing them into four components categories of designer, knowledge, skills, and technology support, which are essential to the model based on the four dimensions of creativity (person, environment, process, and product) [27][28], (iii) mapping of components by determining their relationship and visualizing via diagrams, based on the Input, Process, and Output model [29][30]; (iv) Expert verification to validate the components in the model using the Inter Rater Reliability (IRR) technique by four experts from the gaming industry and academia [31][32]. Fig. 2 summaries the activities performed in the design phase.

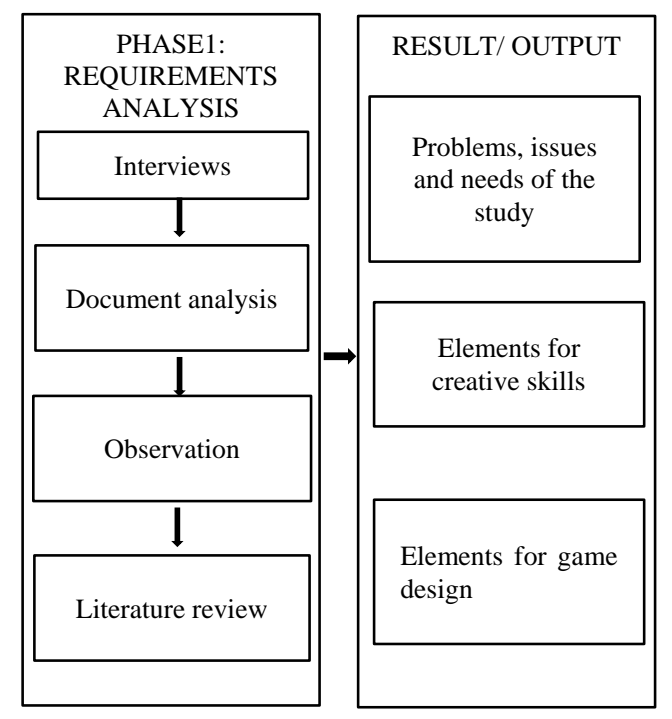

Fig. 1. Requirement Planning Phase.

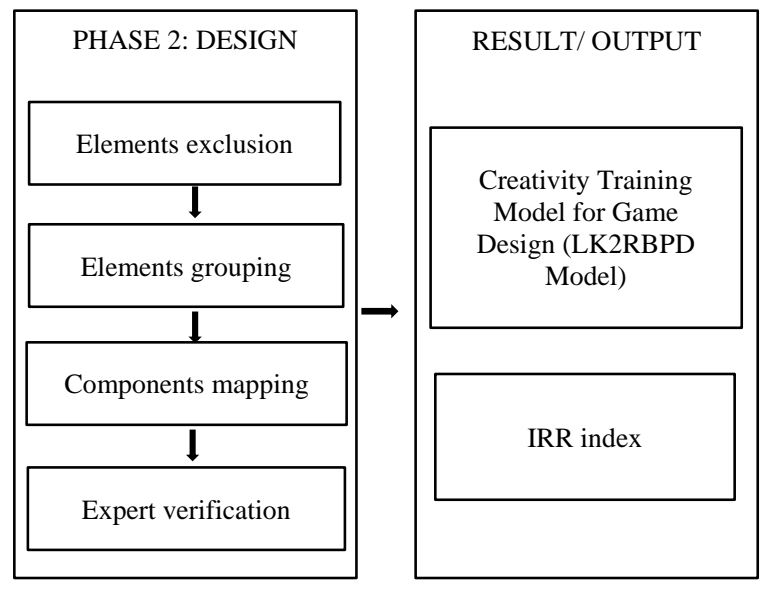

Fig. 2. Design Phase.

\section{Development Phase}

The development phase involves five activities. The first activity is prototype development with implementation of the LK2RBPD Model - the GDD Tool. Second activity is verification of the LK2RBPD Model component in the GDD Tool prototype, conducted by five $(5)$ experts (Numbers $(\mathrm{N})=$ 5: Male $(\mathrm{M})=1$; Female $(\mathrm{F})=4$ ) comprising of two game industry experts and three academic specialists / lecturers of game design and development. Semi-structured interview method using a checklist and a low fidelity prototype were used. The third activity is the prototype test, conducted using Thinking Aloud Testing [33] with five students majoring in game design. In the test's procedure, testers would be logged 
in as system users, and they would follow the instructions given to test the GDD Tool's features: choosing roles, generating ideas, brainstorming, and downloading game design documents. Additionally, respondents would need to provide feedback on the low prototype design of the GDD Tool in the checklist provided. The fourth activity is the questionnaire (instrument) development for content validation on the implementation of the LK2RBPD Model component. A 5-point Likert's Scale (1 = strongly disagree, 2 = strongly disagree, $3=$ neutral, $4=$ agree, $5=$ strongly agree) questionnaire consisted of 83 questions has three main sections: part A (student information), part B (question items according to the LK2RBPD Model component), and part $\mathrm{C}$ (SWOT Analysis). Five experts $(\mathrm{N}=5: \mathrm{M}=1 ; \mathrm{F}=4)$ from various fields of expertise validated the questionnaire. Finally, a pilot study was conducted with 15 students for reliability testing of the instrument. Fig. 3 summarizes the activities in the development phase.

\section{Implementation and Testing Phase}

In this phase, the GDD Tool prototype was evaluated through 45 students-perception questionnaire survey. Descriptive mean score used three-level indicators: 0.00 - 1.67 = low, 1.68 - $3.34=$ medium, and 3.35 - $5.00=$ high [34] [35]. Finally, creativity and innovation was evaluated based on observations on ideation process and the game design documents (GDD) produced through GDD Tool. GDD were assessed by five experts, who are game designers. The evaluation was carried out in two sessions. The first session was conducted without using the GDD Tool, in the form of a regular discussion. The researcher provided the students with instructions on the production of game design documents and gave them some ideas on game design. The second session required the GDD Tool, so the testing procedure was initiated with a demonstration that provided the respondents with instructions on how to use the GDD Tool. Fig. 4 shows a summary of the activities in this phase.

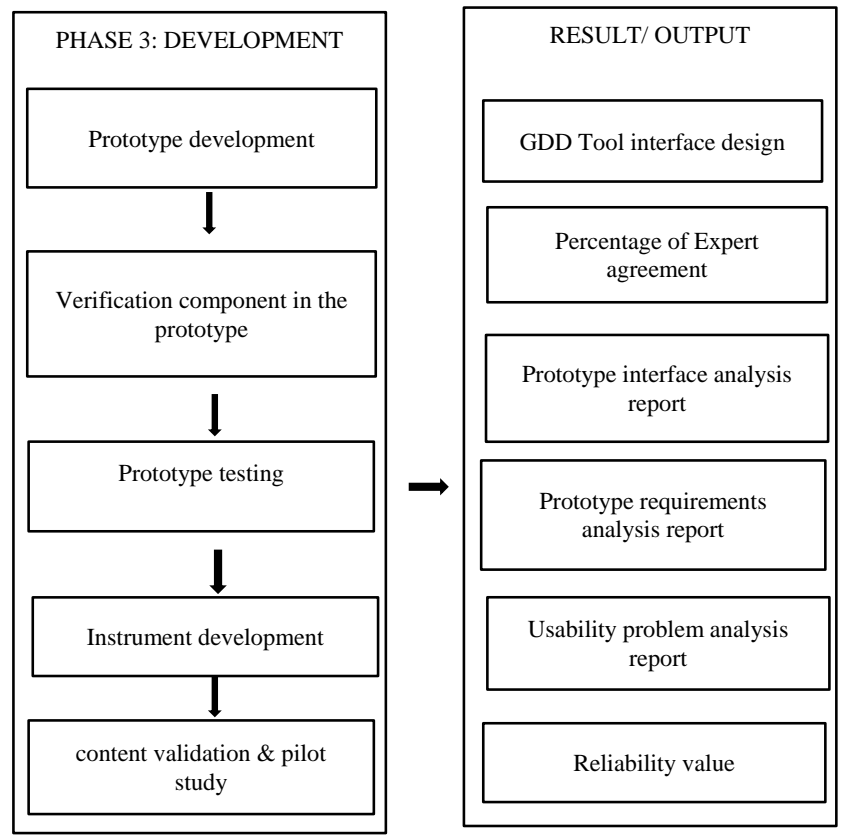

Fig. 3. Development Phase.

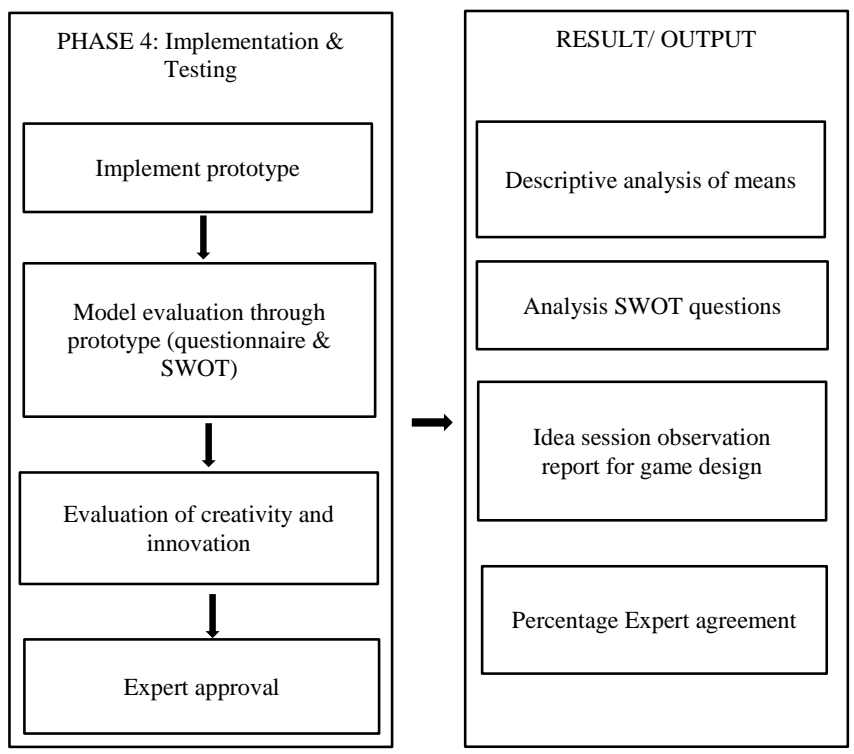

Fig. 4. Implementation and Testing Phase.

\section{RESULTS AND DISCUSSION}

Results identified from requirements analysis were 19 elements essential for training creative skills in game design, consisting of industry practices, creative and innovative thinking skills, creativity dimensions, Sternberg's theory of creativity, and cultural activity theory. These elements were grouped into four components: (1) the designer component consists of elements (intelligence, thinking style, motivation and personality) while (2) the knowledge component consists of the elements (experience, game genre, environment and storyline) next (3) the skills component consists of the elements (linking, synthesizing, imitation, game analysis, generating ideas, inventing and play centric) and last (4) the technology support component that consists of elements (goals, rules, community, and distribution of tasks), forming the LK2RBPD Model.

The IRR approval rate for expert validation of the model is 94 percent, an acceptable level of trust agreement. IRR values from 75 percent to 90 percent indicate acceptable levels of agreement when using a percentage of consent [31] [32] [35]. Fig. 5 shows the LK2RBPD Model with 19 components (intelligence, thinking style, motivation, personality, experience, game genre, environment, storyline, correlate, synthesis, imitation, game analysis, generate idea, invent, play centric, goals, rules, community and task distribution. Model construction and validation has been discussed in detail in [36].

The model evaluation is done via the GDD Tool low fidelity prototype. Results of the experts' agreement on the implementation of the LK2RBPD Model components in the GDD Tool's low-fidelity prototype is good (Cohen Kappa coefficient $=0.84$ ) [37]. However, only 17 components of the model were identified and agreed upon by all the experts (Table I). Table II shows the experts' feedback on GDD Tool prototype interface. Experts' feedback using the provided checklist was then used to develop the final prototype, based on the system requirements (Table III). 
Creativity Training Model for Game Design

INPUT

PROCESS

OUTPUT
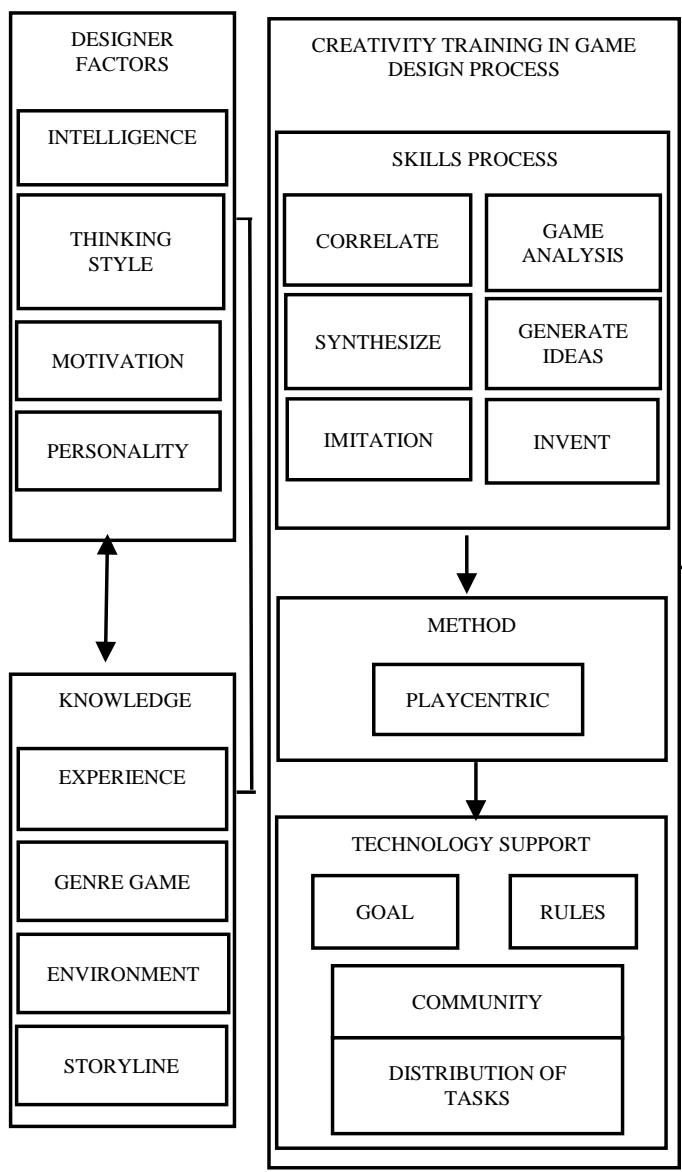

Fig. 5. LK2RBPD Model.

TABLE I. EXPERTS’ AGREEMENT ON THE IMPLEMENTATION THE LK2RBPD MODEL COMPONENTS

\begin{tabular}{|l|l|l|l|l|l|l|}
\hline No & Components & Expert1 & $\begin{array}{l}\text { Expert } \\
\mathbf{2}\end{array}$ & $\begin{array}{l}\text { Expert } \\
\mathbf{3}\end{array}$ & $\begin{array}{l}\text { Expert } \\
\mathbf{4}\end{array}$ & $\begin{array}{l}\text { Expert } \\
\mathbf{5}\end{array}$ \\
\hline 1. & Intelligence & $/$ & $/$ & $/$ & $/$ & $/$ \\
\hline 2. & Thinking style & $/$ & $/$ & $/$ & $/$ & $/$ \\
\hline 3. & Motivation & $X$ & $X$ & $X$ & $X$ & $X$ \\
\hline 4. & Personality & $/$ & $/$ & $/$ & $/$ & $/$ \\
\hline 5. & Experience & $/$ & $/$ & $/$ & $/$ & $/$ \\
\hline 6. & Game Genre & $/$ & $/$ & $/$ & $/$ & $/$ \\
\hline 7. & Environment & $X$ & $X$ & $X$ & $X$ & $X$ \\
\hline 8. & Storyline & $/$ & $/$ & $/$ & $/$ & $/$ \\
\hline 9. & Correlate & $/$ & $/$ & $/$ & $/$ & $/$ \\
\hline 10 & Synthesise & $/$ & $/$ & $/$ & $/$ & $/$ \\
\hline 11. & Imitation & $/$ & $X$ & $/$ & $/$ & $X$ \\
\hline 12 & Game analysis & $/$ & $/$ & $/$ & $/$ & $/$ \\
\hline 13. & Generate ideas & $/$ & $/$ & $/$ & $/$ & $/$ \\
\hline 14. & Invent & $/$ & $/$ & $/$ & $/$ & $/$ \\
\hline
\end{tabular}

\begin{tabular}{|c|l|l|l|l|l|l|}
\hline 15. & Play centric & $/$ & $/$ & $/$ & $/$ & $/$ \\
\hline 16. & Goal & $/$ & $/$ & $/$ & $/$ & $/$ \\
\hline 17. & Rules & $/$ & $/$ & $/$ & $/$ & $/$ \\
\hline 18. & Community & $/$ & $/$ & $/$ & $/$ & $/$ \\
\hline 19. & $\begin{array}{l}\text { Distribution of } \\
\text { tasks }\end{array}$ & $/$ & $/$ & $/$ & $/$ & $\mathrm{X}$ \\
\hline
\end{tabular}

TABLE II. EXPERT FEEDBACK ON GDD TOOL PROTOTYPE INTERFACE

\begin{tabular}{|c|c|c|}
\hline No & $\begin{array}{l}\text { Elements of Prototype } \\
\text { interface }\end{array}$ & Suggestion for improvement \\
\hline 1. & Colour usage & $\begin{array}{l}\text { - Change the background colour to } \\
\text { make it a more vibrant, engaging and } \\
\text { effective design. } \\
\text { - } \quad \text { Ensure appropriate and consistent use } \\
\text { of colours and combinations on each } \\
\text { interface. } \\
\text { - Consistent use of colour for each } \\
\text { menu button on the interface. }\end{array}$ \\
\hline 2. & $\begin{array}{l}\text { Text/Fonts style and } \\
\text { size }\end{array}$ & $\begin{array}{l}\text { - Change text style and size for } \\
\text { communicating purposes, } \\
\text { - } \quad \text { Sensitive font: for computer display. } \\
\text { - Sans serif font types are more } \\
\text { commonly used because it's more } \\
\text { accurate for inside use of computer } \\
\text { resolution. } \\
\text { The choice of style and text size } \\
\text { should be more appropriate to explain } \\
\text { how the generated application works, } \\
\text { to guide the user to browse the } \\
\text { application, and to send information } \\
\text { to the designed application. } \\
\text { Consistent use of text size for page } \\
\text { title, description of words in words or } \\
\text { paragraphs and instructions for } \\
\text { operating the application. } \\
\text { Use of the title of each interface in } \\
\text { accordance with the functions and } \\
\text { processes that will be used by the } \\
\text { GDD Tool user. } \\
\text { Consistent use of English. }\end{array}$ \\
\hline 3. & Menus & $\begin{array}{l}\text { - Add menu buttons to the Comment } \\
\text { Page and Best Ideas interface for the } \\
\text { purpose of providing the client with a } \\
\text { flow of games in the diagram (for } \\
\text { better understanding). } \\
\text { - Add a critic menu button to the } \\
\text { Client's Idea interface. } \\
\text { Add an Edit button to the Game } \\
\text { Design Document interface. } \\
\text { Use a consistent and appropriate } \\
\text { menu button design to ensure that } \\
\text { users are aware of the existence of } \\
\text { buttons and functions. } \\
\text { The menu button position is placed in } \\
\text { the centre of the interface. } \\
\text { The position of the client name is } \\
\text { arranged in a more organised manner } \\
\text { on the Client Name interface. }\end{array}$ \\
\hline 4. & Sequence of Action & $\begin{array}{l}\text { - The Rules interface is placed on the first } \\
\text { interface of the GDD Tool application } \\
\text { so that users can better understand the } \\
\text { rules when using the GDD Tool. }\end{array}$ \\
\hline
\end{tabular}


TABLE III. GDD TOOL PROTOTYPE REQUIREMENTS

\begin{tabular}{|c|c|c|}
\hline No & $\begin{array}{l}\text { Prototype } \\
\text { Requirements }\end{array}$ & Suggestion and improvement \\
\hline 1. & Input & $\begin{array}{l}\text { - The instructions should be clear for each } \\
\text { interface that requires text input from the user. } \\
\text { - Suggest options for emoticons or Likes on the } \\
\text { Comment Page interface. } \\
\text { - The Best Ideas interface reward/likes function to } \\
\text { enhance user motivation. }\end{array}$ \\
\hline 2. & Process & $\begin{array}{l}\text { - Functional enhancements to the Role Select } \\
\text { interface according to the MDA Framework } \\
\text { game design framework which is Mechanics } \\
\text { designer, Dynamics designer and Aesthetics } \\
\text { designer. } \\
\text { - Enhanced chat between clients. }\end{array}$ \\
\hline 3. & Output & $\begin{array}{l}\text { - Need to display instructions or information } \\
\text { about the GDD Tool on the first interface that is } \\
\text { represented by the Help/About/Rules button. } \\
\text { - Replace the rule sentence with the } \\
\text { illustration/flow chart/video/animation in the } \\
\text { Rules interface. } \\
\text { - Need statement or instructions for user to } \\
\text { download document in doc/pdf format. }\end{array}$ \\
\hline 4. & Data source & $\begin{array}{l}\text { - Must have a stable domain for easy access to } \\
\text { developed applications. }\end{array}$ \\
\hline 5. & Control & $\begin{array}{l}\text { - Functions added to the Game Design Document } \\
\text { interface - only hosts are given the functionality } \\
\text { to edit, update, and submit. } \\
\text { - Extension of time given to client on Comment } \\
\text { Page interface according to eureka concept. }\end{array}$ \\
\hline
\end{tabular}

System requirements analysis is part of the initial study to identify system-specific problems and requirements, including input requirements, process requirements, output requirements, data handling, and system control resources. System-specific requirements are specifications of what the system will do when implemented [38]. Table III shows an analysis of the GDD Tool prototype requirements.

Usability Testing allows users to try using a real prototype or an application of a particular task. The goal is to find out how well the designed application or service can be used, so that any arising problem can be highlighted or discovered during testing [33]. For usability testing (pilot test) of the GDD tool prototype, five tasks were assigned to 5 users, and 8 problems were identified. The list of usability issues is shown in Table IV.

The agreement on the prototype usability problems, the Cohen Kappa coefficient is 0.54 , which indicates a mediumscale level usability problem for the GDD Tool. This value implied that although improvements to the usability problems or issues should still be made, the GDD Tool prototype can be used by the user without major complications. Many of the problems encountered in the test were related to the respondents' misunderstanding the purpose of the GDD Tool application or their inability to identify the next steps in the application process, similar to the problems found by [39] [40] [41] in studies done with more experienced users. Additionally, the reliability value of the Cronbach's alpha was 0.84 , indicating that the questionnaire items had reliability [37], so can be used for final evaluation.
TABLE IV. USABILITY PROBLEMS OF GDD TOOL PROTOTYPE

\begin{tabular}{|c|c|c|c|c|}
\hline No & Tasks (T) & $\begin{array}{l}\text { Code Problen } \\
\text { (P) }\end{array}$ & Problems & User (U) \\
\hline 1. & $\begin{array}{l}\text { Task 1: } \\
\text { User needs to } \\
\text { join the idea } \\
\text { brainstorming } \\
\text { session (T1) }\end{array}$ & P1 & $\begin{array}{l}\text { Users do not know } \\
\text { how to start the } \\
\text { application. }\end{array}$ & $\begin{array}{l}\text { U1, U2, } \\
\text { U3, U4, } \\
\text { U5 }\end{array}$ \\
\hline 2. & $\begin{array}{l}\text { Task 2: } \\
\text { User needs to } \\
\text { select a role in } \\
\text { the GDD Tool. } \\
\text { (T2) }\end{array}$ & $\begin{array}{l}\text { P2 } \\
\text { P3 }\end{array}$ & $\begin{array}{l}\text { Users are not clear } \\
\text { about their role in the } \\
\text { selection process. } \\
\text { Host is not clear } \\
\text { about the role of the } \\
\text { GDD Tool. }\end{array}$ & $\begin{array}{l}\text { U1, U2, } \\
\text { U4 } \\
\text { U5 }\end{array}$ \\
\hline 3. & $\begin{array}{l}\text { Task 3: } \\
\text { Users need to } \\
\text { generate ideas } \\
\text { in game design } \\
\text { (T3) }\end{array}$ & P4 & $\begin{array}{l}\text { Users require more } \\
\text { time beyond the } \\
\text { allocated } 15 \text { minutes } \\
\text { to generate ideas. }\end{array}$ & $\begin{array}{l}\text { U1, U2, } \\
\text { U3, U4, } \\
\text { U5 }\end{array}$ \\
\hline 4. & $\begin{array}{l}\text { Task 4: } \\
\text { Users need to } \\
\text { brainstorm and } \\
\text { choose } \\
\text { creative game } \\
\text { design ideas } \\
\text { (T4) }\end{array}$ & $\begin{array}{l}\text { P5 } \\
\text { P6 } \\
\text { P7 } \\
\text { P8 }\end{array}$ & $\begin{array}{l}\text { Users do not } \\
\text { understand the } \\
\text { instructions provided. } \\
\text { User shows or } \\
\text { expresses impatience } \\
\text { by clicking on the } \\
\text { objects that respond } \\
\text { slowly. } \\
\text { Users show a } \\
\text { tendency to take } \\
\text { actions randomly } \\
\text { (intentionally or } \\
\text { otherwise). } \\
\text { Button disappears } \\
\text { when clicked. }\end{array}$ & $\begin{array}{l}\text { U1, U2, } \\
\text { U4 } \\
\text { U1 } \\
\text { U1, U2 } \\
\text { U4, U5 }\end{array}$ \\
\hline 5. & $\begin{array}{l}\text { Task 5: } \\
\text { Users need to } \\
\text { create and } \\
\text { download } \\
\text { Game Design } \\
\text { Document } \\
\text { GDDD (T5) }\end{array}$ & & No issue & $\begin{array}{l}\text { U1, U2, } \\
\text { U3, U4, } \\
\text { U5 }\end{array}$ \\
\hline
\end{tabular}

The final results from questionnaire survey show that all the components of the LK2RBPD Model have high ratings. Overall, the analysis showed that 19 components of the LK2RBPD Model have high mean reading scores of 4.11 to 4.30, as shown in Table V.

Results of SWOT analysis of the GDD Tool prototype is shown in Table VI. Theme analysis was used to sort out answers based on themes of strengths, weaknesses, opportunities, and threats.

The results of the SWOT analysis show that the prototype has strengths and opportunities. However, some threats and weaknesses in the areas of technology need to be improved, such as internet accessibility, poor information sharing, misuse of application features, and competition from social applications.

Finally, the result of creativity and innovation evaluation based on the ideation session process is presented in Table VII while experts' evaluation of the game design documents using the GDD Tool prototype is in Table VIII. 
TABLE V. MIN SCORES AND STANDARD DEVIATIONS FROM SURVEY QUESTIONNAIRE IMPLEMENTATION MODEL LK2RBPD

\begin{tabular}{|l|l|l|l|}
\hline No & Construct & Min Scores & Standard Deviations \\
\hline 1 & Intelligence & 4.21 & 0.63 \\
\hline 2 & Thinking style & 4.30 & 0.59 \\
\hline 3 & Motivation & 4.20 & 0.57 \\
\hline 4 & Personality & 4.16 & 0.71 \\
\hline 5 & Experience & 4.11 & 0.67 \\
\hline 6 & Game Genre & 4.20 & 0.64 \\
\hline 7 & Environment & 4.28 & 0.58 \\
\hline 8 & Storyline & 4.25 & 0.63 \\
\hline 9 & Correlate & 4.28 & 0.59 \\
\hline 10 & Synthesise & 4.30 & 0.59 \\
\hline 11 & Imitation & 4.23 & 0.67 \\
\hline 12 & Game analysis & 4.33 & 0.58 \\
\hline 13 & Generate ideas & 4.26 & 0.62 \\
\hline 14 & Invent & 4.21 & 0.59 \\
\hline 15 & Play-centric & 4.24 & 0.55 \\
\hline 16 & Goal & 4.23 & 0.61 \\
\hline 17 & Rules & 4.23 & 0.57 \\
\hline 18 & Community & 4.23 & 0.65 \\
\hline 19 & Distribution of tasks & 4.32 & 0.54 \\
\hline & & & \\
\hline
\end{tabular}

TABLE VI. SWOT ANALYSIS

\begin{tabular}{|l|l|}
\hline Team & Answer \\
\hline & $\begin{array}{l}\text { "Can play more than once anywhere" } \\
\text { "Able to come up with ideas and create stories } \\
\text { quickly" } \\
\text { "It really helps to come up with ideas" } \\
\text { "Can improve a lot of ideas" } \\
\text { "Lots of creative ideas" } \\
\text { "Being able to talk online with a group of friends to } \\
\text { build the best game design" } \\
\text { "GDD tool helps me to know more about the process } \\
\text { of creating game designs, game design documents" } \\
\text { "Being able to share ideas and stimulate creative } \\
\text { ideas" } \\
\text { "GDD Tool can improve creative thinking skills" } \\
\text { "I can think a lot" } \\
\text { "Being able to connect with friends and talk about } \\
\text { game design ideas" } \\
\text { "Each user can play their own role" } \\
\text { "Get lots of creative ideas" } \\
\text { "Developing ideas for the better }\end{array}$ \\
\hline $\begin{array}{l}\text { "The interface can be improved to make it more } \\
\text { interesting” } \\
\text { "Needs strong internet access" } \\
\text { "Host role may expand" } \\
\text { "No rules on the voting site need complete } \\
\text { instructions" } \\
\text { "Add community members for more ideas" } \\
\text { "No images led to the development of game ideas" }\end{array}$ \\
\hline Weaknesses
\end{tabular}

\begin{tabular}{|c|c|}
\hline Opportunities & $\begin{array}{l}\text { "It's accessible everywhere but it's still a one-on-one } \\
\text { session for developing creative ideas in game design" } \\
\text { "Be able to train yourself to think creatively" } \\
\text { "Can be used many times" } \\
\text { "Can easily create GDD” } \\
\text { "Can add other functions like audio and other" } \\
\text { "Allows sharing of ideas anywhere" } \\
\text { "Can be used by everyone" } \\
\text { "Students get ideas for game design" } \\
\text { "Final semester students will gain more and more } \\
\text { knowledge in game design when using the GDD Tool } \\
\text { " } \\
\text { "Can expand the use of the GDD Tool to other } \\
\text { students / institutions" } \\
\text { "Can introduce this GDD Tool to other colleges that } \\
\text { have gaming programs" } \\
\text { "Can be a training tool for train creative thinking" } \\
\text { "Allows many people to use it well" }\end{array}$ \\
\hline Threats & $\begin{array}{l}\text { "Too easy to disconnect" } \\
\text { "Requires a strong internet connection" } \\
\text { "Theft of ideas can happen” }\end{array}$ \\
\hline
\end{tabular}

TABLE VII. IDEATION SESSION REPORT

\begin{tabular}{|c|c|}
\hline $\begin{array}{l}\text { Discussions without using the } \\
\text { GDD Tool: }\end{array}$ & Discussions using the GDD Tool: \\
\hline $\begin{array}{l}\text { - There is no fixed time on when } \\
\text { to start the discussion. }\end{array}$ & $\begin{array}{l}\text {-The discussion session is } \\
\text { conducted at a time that is set } \\
\text { and controlled by a Host. }\end{array}$ \\
\hline $\begin{array}{l}\text { - Discussions take long time and } \\
\text { waste of time without any } \\
\text { brainstorming activity. }\end{array}$ & $\begin{array}{l}\text { - The discussion is clearly set out } \\
\text { in accordance with the goals and } \\
\text { rules set in the GDD Tool. }\end{array}$ \\
\hline $\begin{array}{l}\text { - Does not achieve the actual goal } \\
\text { of the discussion. }\end{array}$ & $\begin{array}{l}\text { - Community members have the } \\
\text { time and platform to generate } \\
\text { ideas. }\end{array}$ \\
\hline $\begin{array}{l}\text { - All members of the community } \\
\text { want to talk at the same time. }\end{array}$ & $\begin{array}{l}\text { - Ideas are generated based on the } \\
\text { keywords provided in the GDD } \\
\text { Tool. }\end{array}$ \\
\hline $\begin{array}{l}\text { - There is no platform for } \\
\text { channelling ideas. }\end{array}$ & - Ideas can be created creatively. \\
\hline $\begin{array}{l}\text { - Ideas are written on paper and } \\
\text { difficult to keep. }\end{array}$ & $\begin{array}{l}\text { - Each member's ideas can be } \\
\text { shared with other community. }\end{array}$ \\
\hline $\begin{array}{l}\text { - The discussion took a long time } \\
\text { because there was no proper } \\
\text { monitoring and distribution of } \\
\text { tasks among the members }\end{array}$ & $\begin{array}{l}\text { - Using the GDD Tool can train } \\
\text { creative thinking for game ideas, } \\
\text { while game designers can } \\
\text { develop their imagination and } \\
\text { introduce new game ideas that } \\
\text { can be produced. }\end{array}$ \\
\hline $\begin{array}{l}\text { - Difficult to generate ideas. } \\
\text { - The situation cannot be } \\
\text { controlled and it is difficult to } \\
\text { obtain conclusion on the game } \\
\text { design. }\end{array}$ & $\begin{array}{l}\text { - Generate formal ideas by } \\
\text { developing mechanics, } \\
\text { dynamics and aesthetics } \\
\text { elements in game design. }\end{array}$ \\
\hline $\begin{array}{l}\text { - Ideas can be produced, but not } \\
\text { made in a complete game } \\
\text { design document, instead just } \\
\text { drawings and notes that cannot } \\
\text { be referenced. }\end{array}$ & $\begin{array}{l}\text { - Ideas are improved as they are } \\
\text { generated based on game } \\
\text { objectives, user targets, game levels, } \\
\text { and game names. }\end{array}$ \\
\hline \multirow{2}{*}{$\begin{array}{l}\text { - Each member's ideas cannot be } \\
\text { shared with other community } \\
\text { partners. }\end{array}$} & $\begin{array}{l}\text { - A complete and creative game } \\
\text { design document can be created } \\
\text { as soon as the GDD Tool usage } \\
\text { session ends. }\end{array}$ \\
\hline & $\begin{array}{l}\text { - Game design documents can use } \\
\text { as a reference for the game } \\
\text { development phase. }\end{array}$ \\
\hline
\end{tabular}


A total of nine (9) game design documents were produced from the use of the GDD Tool session by 45 respondent focus groups of students majoring in game design and development. GDDs analysis produced a total of 72 data (ideas). The experts' agreement on the creative game design ideas is 97 per cent. For comparison, the level of expert agreement is calculated using Cohen Kappa formula, K: 0.94 (94\%), which signifies excellent agreement [42]. The evaluation results confirm that the LK2RBPD Model could be used effectively to develop and train creativity in game design. Table VIII and Table IX show the experts agreement on game design ideas derived from the final test of the GDD Tool prototype.

TABLE VIII. EXPERTS’ APPROVAL

\begin{tabular}{|l|l|l|l|l|l|l|}
\hline $\begin{array}{l}\text { Game } \\
\text { Design } \\
\text { Document }\end{array}$ & $\begin{array}{l}\text { Expert } \\
\mathbf{1}\end{array}$ & $\begin{array}{l}\text { Expert } \\
\mathbf{2}\end{array}$ & $\begin{array}{l}\text { Expert } \\
\mathbf{3}\end{array}$ & $\begin{array}{l}\text { Expert } \\
\mathbf{4}\end{array}$ & $\begin{array}{l}\text { Expert } \\
\mathbf{5}\end{array}$ & $\mathbf{( \% )}$ \\
\hline $\begin{array}{l}\text { Creative } \\
\text { Game Design } \\
\text { Ideas }\end{array}$ & 72 & 72 & 72 & 72 & 72 & 100 \\
\hline Agreement & 67 & 70 & 72 & 72 & 69 & 70 \\
\hline $\begin{array}{l}\text { Percent } \\
\text { Agreement }\end{array}$ & 93 & 97 & 100 & 100 & 95 & 97 \\
\hline
\end{tabular}

TABLE IX. CALCULATION OF EXPERTS’ APPROVAL USING THE COHEN KAPPA FORMULA

\begin{tabular}{|c|c|c|c|c|c|c|}
\hline Step & \multicolumn{6}{|c|}{ Calculation } \\
\hline $\begin{array}{l}\text { Step } \\
1\end{array}$ & \multicolumn{6}{|c|}{$\begin{array}{l}\text { Formula: } \\
\mathrm{K}=\underline{\text { fo-fc }} \\
\mathrm{N}-\mathrm{fc} \\
\text { fo- Agreement } \\
\text { fc- } 50 \text { Expectation percent agreement } \\
\mathrm{N} \text { - Number of game design ideas }\end{array}$} \\
\hline \multirow{5}{*}{$\begin{array}{l}\text { Step } \\
2\end{array}$} & \multicolumn{6}{|c|}{ Calculation } \\
\hline & $\begin{array}{l}\text { Expert } \\
1\end{array}$ & Expert 2 & $\begin{array}{l}\text { Expert } \\
3\end{array}$ & $\begin{array}{l}\text { Expert } \\
4\end{array}$ & Expert 5 & $\begin{array}{c}\text { Expert } \\
\text { Agreement }\end{array}$ \\
\hline & $\begin{array}{l}\text { fo }= \\
67 \\
\text { fc }=36 \\
N=72\end{array}$ & $\begin{array}{l}\text { fo }=70 \\
\text { fc }=36 \\
N=72\end{array}$ & $\begin{array}{l}\text { fo }=72 \\
\text { fc }=36 \\
N=72\end{array}$ & $\begin{array}{l}\text { fo }=72 \\
\text { fc }=36 \\
N=72\end{array}$ & $\begin{array}{l}\text { fo }=69 \\
\text { fc }=36 \\
N=72\end{array}$ & \multirow{2}{*}{$\begin{array}{l}K=0.86 \\
+0.94+ \\
1.0+1.0 \\
+0.91\end{array}$} \\
\hline & $\begin{array}{l}\mathrm{K}=\mathrm{fo}- \\
\mathrm{fc} \\
\mathrm{N}-\mathrm{fc}\end{array}$ & $\begin{array}{l}K=\underline{\text { fo-fc }} \\
N-f c\end{array}$ & $\begin{array}{l}\mathrm{K}=\mathrm{fo}-\mathrm{fc} \\
\mathrm{N}-\mathrm{fc}\end{array}$ & $\begin{array}{l}\mathrm{K}=\text { fo- } \\
\frac{\mathrm{fc}}{\mathrm{N}-\mathrm{fc}}\end{array}$ & $\begin{array}{l}K=\text { fo-fc } \\
N-f c\end{array}$ & \\
\hline & $\begin{array}{l}\mathrm{K}=\underline{67-} \\
\underline{36} \\
72-36 \\
\mathrm{~K}=\underline{31} \\
36 \\
\mathrm{~K}= \\
0.86\end{array}$ & $\begin{array}{l}\mathrm{K}=\underline{70-36} \\
72-36 \\
\mathrm{~K}=\underline{34} \\
36 \\
\mathrm{~K}=0.94\end{array}$ & $\begin{array}{l}\mathrm{K}=\underline{72-36} \\
72-36 \\
\mathrm{~K}=\underline{36} \\
36 \\
\mathrm{~K}=1.0\end{array}$ & $\begin{array}{l}\mathrm{K}=\underline{72-} \\
\underline{36} \\
72-36 \\
\mathrm{~K}=\underline{36} \\
36 \\
\mathrm{~K}= \\
1.0\end{array}$ & $\begin{array}{l}\mathrm{K}=\underline{69-36} \\
72-36 \\
\mathrm{~K}=\underline{33} \\
36 \\
\mathrm{~K}=0.91\end{array}$ & $\begin{array}{l}5 \\
\mathrm{~K}=\underline{4.71} \\
5 \\
\mathbf{K}=\mathbf{0 . 9 4}\end{array}$ \\
\hline
\end{tabular}

\section{CONCLUSION AND IMPLICATIONS}

This study successfully identified 19 components of the LK2RBPD Model and implemented them in the GDD Tool prototype. Evaluation results of the LK2RBPD Model components in the GDD Tool prototype, and the assessment of creativity and innovation in the game design confirmed that the LK2RBPD Model could be used for training the creative skills of game design to produce game. The results of this study successfully identified 19 components of the LK2RBPD Model and implemented them in the GDD Tool prototype.
Evaluation result of the LK2RBPD Model components in the GDD Tool prototype, and the assessment of creativity and innovation in the game design confirmed that the LK2RBPD Model could be used for training the creative skills of game design to produce game design documents. Evaluation result of the LK2RBPD Model components through the use of the GDD Tool prototype indicated a rating higher than 4.0, which means that the GDD Tool prototype can be used to train creative skills in game design. As for the results of experts' agreement on creativity and innovation in game design, creative game design documents showed an excellent agreement of 97 per cent or K: 0.94 . This shows that creative skills can be trained by involving the important and necessary components of the LK2RBPD model in producing a creative game design. Apart from that, technological aids/tools also help train creative skills in game design. The results of this study have identified three (3) guidelines that need to be in place to generate a creative idea and can be used as a reference for game designers in the process of generating creative game design ideas. This study found that creative thinking can be trained on each individual in particular, to produce a creative game design document by following these three guidelines: (i) ideas are generated through a selection process of some of the best ideas, ii) the ideas produced need to be targeted such as the target user, game name, game objectives and game level and iii) idea generation needs to be more formal that is according to the rules of form, characteristics and certain ways that are acceptable and considered appropriate according to the rules or steps necessary in a game design. The five experts in the field of game design agreed that creative skills training is effective in developing creativity and innovation in the ideation phase of game design. Individuals could be trained successfully in creative thinking, as well as to develop creative ideas by implementing the 19 components of the LK2RBPD Model. The results demonstrate that the objectives of the study have been achieved and the LK2RBPD Model can help solve some problems in this research area. However, further research can be carried out with the use of elements involving creativity and innovation as well as other appropriate training and learning theories according the needs to train creative skills in game design. In addition, the improvement of GDD tools in various platforms with the use of more interactive elements such as chat rooms, image uploads, videos, animations and software functions according to the latest trends that can be used as a communication platform to game designers in producing a creative game design.

\section{ACKNOWLEDGMENT}

We acknowledge the assistance from Metro Polytechnic Kuala Lumpur and the Polytechnic and Community College Department, University Kebangsaan Malaysia (UKM) for supporting the research under grant GUP-2019-059 and HLP Federal Training Specialist, Ministry of Higher Education Malaysia for funding the study.

\section{REFERENCES}

[1] Chernyakov, M., \& Chernyakova, M. Technological risks of the digital есопоту. Корпоративные финансы, 12(4), 2018.

[2] Sharif, M., Zafar, A., \& Muhammad, U. Design patterns and general video game level generation. International Journal of Advanced Computer Science and Applications, 8(9), 393-398, 2017. 
[3] De Freitas, S. Are games effective learning tools? A review of educational games. Journal of Educational Technology \& Society, 21(2), 74-84, 2018.

[4] Vlachopoulos, D., \& Makri, A. The effect of games and simulations on higher education: a systematic literature review. International Journal of Educational Technology in Higher Education, 14(1), 22, 2017.

[5] Barr, M. Student attitudes to games-based skills development: Learning from video games in higher education. Computers in Human Behavior, 80, 283-294, 2018.

[6] Athavale, S., \& Mohan, A. Understanding Game Ideation Through The Lens Of Creativity Model. In DS 89: Proceedings of The Fifth International Conference on Design Creativity (ICDC 2018), University of Bath, Bath, UK (pp. 176-182), 2018.

[7] Kasurinen, J., Palacin-Silva, M. \& Vanhala, E. What Concerns Game Developers? A Study on Game Development Processes, Sustainability and Metrics. International Workshop on Emerging Trends in Software Metrics, WETSoM (May): 15-21, 2017.

[8] Byun, J., \& Loh, C. S. Audial engagement: Effects of game sound on learner engagement in digital game-based learning environments. Computers in Human Behavior, 46, 129-138, 2015.

[9] Ritchie, G. The evaluation of creative systems. In Computational Creativity (pp. 159-194). Springer, Cham, 2019.

[10] Giannakos, M. N., \& Jaccheri, L. From players to makers: An empirical examination of factors that affect creative game development. International Journal of Child-Computer Interaction, 18, 27-36, 2018.

[11] Guzdial, M., Liao, N., \& Riedl, M. Co-creative level design via machine learning. arXiv preprint arXiv:1809.09420, 2018.

[12] Machado', T. L. D. A., Ramalho, G. L., Alves, C. F., Garcia, V. C., Araujo $^{1}$, L. F., Lemos ${ }^{1}$, V., ... \& do Recife, S. A. Game development guidelines: Practices to avoid conflicts between software and design. Software Engineer, 3, 8, 2010.

[13] Henriksen, D., Mishra, P., \& Fisser, P. Infusing creativity and technology in 21st century education: A systemic view for change. Educational Technology \& Society, 19(3), 27-37, 2016.

[14] Chee, C. M., \& Wong, D. H. T. Affluent gaming experience could fail gamification in education: a review. IETE Technical Review, 34(6), 593-597, 2017.

[15] Hendrik, B., Ali, N. M., \& Nayan, N. M. Robotic Technology for Figural Creativity Enhancement: Case Study on Elementary School. International Journal Of Advanced Computer Science And Applications, 11(1), 2020.

[16] Hook, K. Designing with the body: somaesthetic interaction design. MIT Press, 2018.

[17] Friesike, S., Flath, C. M., Wirth, M., \& Thiesse, F. Creativity and productivity in product design for additive manufacturing: Mechanisms and platform outcomes of remixing. Journal of Operations Management, 65(8), 735-752, 2019.

[18] Kanode, C. M. \& Haddad, H. M. Software engineering challenges in game development. ITNG 2009 - 6th International Conference on Information Technology: New Generations 260-265, 2019.

[19] O’Hagan, A. O., Coleman, G., \& O’Connor, R. V. Software development processes for games: A systematic literature review. In European Conference on Software Process Improvement (pp. 182-193). Springer, Berlin, Heidelberg, 2014.

[20] Refai, J. J., Bateman, S., \& Fleming, M. W. External Assistance Techniques that Target Core Game Tasks for Balancing Game Difficulty. Front. Comput. Sci. 2: 17. 2020.

[21] Politowski, C., Fontoura, L., Petrillo, F., \& Guéhéneuc, Y. G. Are the old days gone? A survey on actual software engineering processes in video game industry. In Proceedings of the 5th International Workshop on Games and Software Engineering (pp. 22-28), 2016.

[22] Kasurinen, J., Palacin-Silva, M., \& Vanhala, E. What concerns game developers? a study on game development processes, sustainability and metrics. In 2017 IEEE/ACM 8th Workshop on Emerging Trends in Software Metrics (WETSoM) (pp. 15-21). IEEE, 2017.

[23] Harel, R., Schwartz, D., \& Kaufmann, D. The relationship between innovation promotion processes and small business success: the role of managers’ dominance. Review of Managerial Science, 1-24, 2020.
[24] Rutberg, S., \& Bouikidis, C. D. Focusing on the fundamentals: A simplistic differentiation between qualitative and quantitative research. Nephrology Nursing Journal, 45(2), 209-213, 2018.

[25] Yusoff, S. R. M., \& Zin, N. A. M. Design and evaluation of collaborative learning management system (clms) framework for teaching technical subject. In International Conference on Web-Based Learning (pp. 79-89). Springer, Berlin, Heidelberg, 2012.

[26] Garces, S., Pocinho, M., de Jesus, S. N., \& Viseu, J. The impact of the creative environment on the creative person, process, and product. Avaliação Psicologica, 15(2), 169-176, 2016.

[27] Widana, I. W., Sumandya, I. W., Sukendra, I. K., \& Sudiarsa, I. W. Analysis of conceptual understanding, digital literacy, motivation, divergent of thinking, and creativity on the teachers skills in preparing hots-based assessments. Journal of Advance Research in Dynamical \& Control Systems, 12(8), 459-466, 2020.

[28] Subiyakto, A. A., Ahlan, A. R., Putra, S. J., \& Kartiwi, M. Validation of information system project success model: a focus group study. SAGE Open, 5(2), 2158244015581650, 2015.

[29] Mansikka, H., Harris, D., \& Virtanen, K. An input-process-output model of pilot core competencies. Aviation Psychology and Applied Human Factors, 2017.

[30] McDonald, N., Schoenebeck, S., \& Forte, A. Reliability and inter-rater reliability in qualitative research: Norms and guidelines for CSCW and HCI practice. Proceedings of the ACM on Human-Computer Interaction, 3(CSCW), 1-23, 2019.

[31] Belur, J., Tompson, L., Thornton, A., \& Simon, M. Interrater reliability in systematic review methodology: exploring variation in coder decision-making. Sociological methods \& research, 0049124118799372, 2018.

[32] Alhadreti, O., \& Mayhew, P. Rethinking thinking aloud: A comparison of three think-aloud protocols. In Proceedings of the $2018 \mathrm{CHI}$ Conference on Human Factors in Computing Systems (pp. 1-12), 2018.

[33] Hollon, S. D., \& Kendall, P. C. Cognitive self-statements in depression: Development of an automatic thoughts questionnaire. Cognitive therapy and research, 4(4), 383-395, 1980.

[34] Ruiz, F. J., Suárez-Falcón, J. C., \& Riaño-Hernández, D. Validity evidence of the Spanish version of the automatic thoughts question nnaire-8 in Colombia. The Spanish Journal of Psychology, 20, 2017.

[35] Wilhelm, A. G., Rouse, A. G., \& Jones, F. Exploring differences in measurement and reporting of classroom observation inter-rater reliability. Practical Assessment, Research, and Evaluation, 23(1), 4, 2018.

[36] Raudyah Md Tap,Nor Azan Mat Zin and Hafiz Mohd Sarim,"Creative Game Design Training Requirements," International Journal on Advanced Science, Engineering and Information Technology, vol. 11, no. 1, pp. 64-71, 2021.

[37] Holmes, S., Moorhead, A., Bond, R., Zheng, H., Coates, V., \& McTear, $\mathrm{M}$. Usability testing of a healthcare chatbot: Can we use conventional methods to assess conversational user interfaces?. In Proceedings of the 31st European Conference on Cognitive Ergonomics (pp. 207-214), 2019.

[38] Podvezko, V. Determining the level of agreement of expert estimates. International Journal of Management and Decision Making, 8(5-6), 586600, 2007.

[39] Stachtiari, E., Mavridou, A., Katsaros, P., Bliudze, S., \& Sifakis, J. Early validation of system requirements and design through correctness-byconstruction. Journal of Systems and Software, 145, 52-78, 2018.

[40] Morey, S. A., Barg-Walkow, L. H., \& Rogers, W. A. Managing heart failure on the Go: Usability issues with mHealth apps for older adults. In Proceedings of the Human Factors and Ergonomics Society Annual Meeting (Vol. 61, No. 1, pp. 1-5). Sage CA: Los Angeles, CA: SAGE Publications, 2017.

[41] Srikesavan, C., Williamson, E., Cranston, T., Hunter, J., Adams, J., \& Lamb, S. E. An online hand exercise intervention for adults with rheumatoid arthritis (mySARAH): design, development, and usability testing. Journal of medical Internet research, 20(6), 2018.

[42] Zec, S., Soriani, N., Comoretto, R., \& Baldi, I. Suppl-1, M5: high agreement and high prevalence: the paradox of Cohen's Kappa. The open nursing journal, 11, 211, 2017. 